\title{
Harnessing the Antimicrobial Prospects of Mushroom Fungi against Colletotrichum gloeosporioides Penz. Causing Post-Harvest Anthracnose Disease of Mango
}

\author{
M. Gayathri, G. Thiribhuvanamala* and A. S. Krishnamoorthy \\ Department of Plant Pathology, Tamil Nadu Agricultural University, \\ Coimbatore-641 003, India \\ *Corresponding author
}

\section{A B S T R A C T}

\section{Keywords \\ Mango anthracnose, Mushroom fungi, Inhibition percent, Cell free culture filtrate}

\section{Article Info}

Accepted:

05 June 2020

Available Online:

10 July 2020
Mushrooms contain various bio active potential including antifungal, antiviral and antibacterial property. But very limited work has been done on the productive utilization of the antimicrobial properties for plant disease management practices. The current study is formulated to harness the antimicrobial potential of Ganoderma lucidum, Auricularia polytricha, Lentinus edodes, Coprinus sinensis, Schizophyllum commune, Pleurotus florida, Trichloma mastukae, Calocybe indica,Volvariella volvacea, Fomes spp and Pycnoporus sanguineus against Colletotrichum gloeosporioides causing post-harvest anthracnose disease of mango.Results from dual culture test revealed that the Ganoderma lucidum, Auricularia polytricha, Pycnoporus sanguineus and Pleurotus florida showed inhibition of radial mycelial growth with inhibition percentage of 56.3 to 70.77 $\%$.Although the mushrooms screened exhibited varied degree of inhibition of mycelial growth of pathogen, A. polytricha and G.lucidum performed well and the crude cell free culture filtrates from G. lucidum and $A$. polytricha tested at $20^{\text {th }}$ day showed maximum inhibition of $36.33 \%$ and $47.11 \%$ of mycelial growth of C.gloeosporioides by G. lucidum and A. polytricha respectively.These results predicted that the cell free culture filtrate collected contained some antimicrobial compounds that would have been responsible for the antimicrobial effect and offers better scope for development of mycomolecules based fungicide against plant diseases.

\section{Introduction}

Mango is one the well-known ancient fruit in the world known for its high nutritive value, superb flavour, delicious taste.Though this fruit crop is affected by fungi, bacteria and phytoplasma, Mango anthracnose caused by Colletotrichum gloeosporioides Penz being the most important disease leads to severe yield loss due to the pre harvest and post harvest infection even up to 100 per cent ( Jha et al., 2010; Arauz, 2000). Anthracnose disease causes $30-60 \%$ yield losses on mango across different countries of the world causing both qualitative and quantitative losses (Shad et al., 2002; Akem, 2006; Chowdhury and Rahim, 2009, Lakshmi et al., 2011). Under the current scenario, continuous and judicious application of fungicide against the pathogen has resulted in loss of effectiveness of fungicide due to buildup of fungicide resistant pathogen apart from creating environmental 
pollution and health problem.As an alternative, scientists have started probing for antimicrobial bio active compounds from natural source to overcome the current situation. In that context, mushrooms are in the lime light and evoked interest globally for their bioactive compounds that finds application in pharmaceutical and therapeutic values apart from their nutritive value (Poucheret et al., 2006). Mushroom contain various natural compounds with bio active potentials as antifungal, antibacterial, antiviral, antitumor, antinemic, antiinflammatory, anti-allergic, anti-antherogenic, antidiabetic properties( Hatvani,2001; Wasser 2002; Lindequist et al., 2005; Quang et al., 2006). Research is focused towards exploitation of antimicrobial compounds from mushrooms against plant pathogens as is evidenced by the effect of culture filtrates of Lentinula edodes and Clitocybe nuda against Colletotrichum higginsianum (Chen and Huang, 2010), Ganoderma lucidum against Colletotrichum capsici (Priya and Thiribhuvanamala, 2019) and Coprinus comatus against Fusarium oxysporum f.sp. lycopersici and F.oxysporum f.sp.cubense (Jeeva and Krishnamoorthy, 2018). Perusal of literature shows no reports on the antimicrobials from mushrooms against postharvest pathogens. Currently there is increasing attention to derive safe antimicrobials for post-harvest treatments to mitigate the residual issues in fruits and vegetables. In that context, the present study was attempted to test different mushrooms against mango post-harvest anthracnose pathogen Colletotrichum gloeosporioides.

\section{Materials and Methods}

The mango anthracnose pathogen Colletotrichum gloeosporioides and the pure cultures of mushrooms viz Ganoderma lucidum, Auricularia polytricha, Lentinus edodes, Coprinus sinensis, Schizophyllum commune, Fomes spp, Trichloma mastukae, Calocybe indica,Volvariella volvaceae, Pleurotus florida and Pycnoporus sanguineus were obtained from the Department of Plant Pathology, Tamil Nadu Agricultural University,Coimbatore.

\section{Screening of antagonistic potential of} mushroom fungi under in vitro

Mycelial cultures of mushrooms viz., Volvariella volvacea,Pleurotus florida, Ganoderma lucidum, Auricularia polytricha, Lentinus edodes, Coprinus sinensis, Schizophyllum commune, Calocybe indica, Trichloma mastukae, Fomes spp and Pycnoporus sanguineus were screened for their antagonistic potential against Colletotrichum gloeosporioides causing post harvest anthracnose disease of mango by dual culture technique (Dennis and Webster, 1971).

The PDA medium was prepared and poured into Petri dish.A $9 \mathrm{~mm}$ mycelial disc of the mushroom fungi were placed at one side of Petri dish and similarly test pathogen was placed at opposite side of the same Petri dish. The pathogen were inoculated separately which served as control.Three replications were maintained for each treatment.The Petri dishes were incubated at $28 \pm 2^{\circ} \mathrm{C}$. Periodical observations on the mycelial growth, pattern and their antagonistic behaviour were done. The percentage inhibition of mycelial growth in pathogen over control was calculated by using the formula (Vincent, 1947).

Per cent inhibition over control $(\%)=\frac{\text { C }-\mathrm{T}}{\mathrm{C}}$

Where, $\mathrm{C}$ is the radial mycelial growth of the pathogen $(\mathrm{mm})$ in control

$\mathrm{T}$ is the radial mycelial growth of the pathogen $(\mathrm{mm})$ in dual culture plate. 
Testing the efficacy of crude culture filtrates of mushroom fungi against colletotrichum gloeosporioides

\section{Extraction of crude culture filtrates from mycelium of mushroom fungi}

Based on results obtained from the preliminary antagonistic screening of mushroom fungi against C.gloeopsorioides, the mushrooms Auricularia polytricha and Ganoderma lucidum were shown to be effective against Colletotrichum gloeosporioides as shown by the inhibition of mycelial growth of pathogen. The mycelial disc $(9 \mathrm{~mm})$ from 10 days old culture of Auricularia polytricha and Ganoderma lucidum were placed into $250 \mathrm{ml}$ conical flask containing sterilized Potato Dextrose (PD) broth. The flasks were kept in incubator cum shaker at $25^{\circ} \mathrm{C}$ with agitation at $150 \mathrm{rpm}$. After incubation, the mycelial mat was separated from broth using Whatman filter paper No 1. Then the culture filtrate was centrifuged at $10,000 \mathrm{rpm}$ for $10 \mathrm{mins}$. The supernatant was then filtered through the membrane filter $(0.2 \mu \mathrm{m})$ to avoid bacterial contamination. This extract is used as cell free crude culture filtrates. The crude culture filtrate were collected from Auricularia polytricha and Ganoderma lucidum at various periodical intervals viz., $10^{\text {th }}, 15^{\text {th }}, 20^{\text {th }}$ and $25^{\text {th }}$ days of inoculation and tested for mycelial inhibition studies.

\section{Mycelial inhibition test}

The crude culture filtrate of G. lucidum and A. polytricha extracted at various periodical intervals $\left(10^{\text {th }}, 15^{\text {th }}, 20^{\text {th }}, 25\right.$ days $)$ were tested against the mycelial growth of C.gloeosporioides by agar well diffusion technique (Stokes and Ridgway,1980).The PDA medium was poured into the sterilized plates and allowed to solidify. After solidification, four wells were made at equal distance leaving $1 \mathrm{~cm}$ space from edge of the plate using sterilized corkborer. A $100 \mu 1$ of crude culture filtrate of G.lucidum and A.polytricha (separately) was pipetted and poured into the well. Using sterilized cork borer, a $9 \mathrm{~mm}$ mycelial disc of $C$. gloeosporioides from 10 days old culture was placed at the centre of the plates and incubated at room temperature $\left(28 \pm 2^{\circ} \mathrm{C}\right)$. Three replications maintained for each treatment. Sterile water served as control instead of using culture filtrate. The percentage inhibition was calculated by using the formula (Vincent 1947).

\section{Results and Discussion}

The results obtained from this study indicated that mushrooms screened showed various degrees of antagonistic activity against C.gloeopsorioides and it proved the earlier success of derivation of Azoxystrobin from Strobilurus tenacellus against downy mildew and powdery mildew diseases of grapes. In our study, among the mushrooms screened, the mycelium of Auricularia polytricha, Ganoderma lucidum, Pycnoporus sanguineus and Pleurotus florida inhibited the mycelial growth of Colletotrichum gloeosporioides $(26.3 \mathrm{~mm}, 36.6 \mathrm{~mm}, 39.6 \mathrm{~mm}$ and $39.3 \mathrm{~mm}$ respectively) as observed by inhibition per cent of 70.77, 59.33, 56.00 and 56.33 respectively. Other mushrooms, Fomes spp, Volvariella volvacea, Schizophyllum commune, Coprinus sinensis, Calocybe indica and Tricholoma matsukae also showed mycelial growth inhibition of $50.44 \%$, $41.11 \%, 51.88 \%, 50.00 \%, 22.11 \%, 22.66 \%$ respectively against the test pathogen Colletotrichum gloeosporioides (Fig.1).

As in our study, Priya et al., (2018) reported that the antagonistic activity of Ganoderma lucidum followed by Auricularia polytricha against Colletotrichum capsici. Similarly, Badalyan et al., (2014) reported that the 
mushrooms Ganoderma lucidum, Pleurotus ostreatus,Hypholoma fasiculare, Lentinus tigrinus exhibited various antimicrobial activity against Cochliobolus sativus, Fusarium culmorum, Gaeumannomyces graminis and Rhizoctonia cerealis. The interactions between the pathogen Colletotrichum gloeosporioides and the mushroom were documented from the dual culture assay. Plates are given in Table-1. Antagonistic interactions between different mushroom fungi and plant pathogenic fungi in dual cultures and various types of competitive interactions viz., over growth of pathogen, inhibition at mycelial contact, inhibition of mycelia at distance and partial or complete replacement of plant pathogenic fungi were reported by Badalyan,2002; Jeeva and Krishnamoorthy, 2018; Priya et.al., 2019). This clearly shows that the interactions could be due to certain metabolites that would be responsible for the retardation of $\mathrm{C}$. gloeosporioides. These results paved way to exploit antimicrobial metabolites from potential mushrooms G.lucidum and A.polytricha against $C$. gloeosporioides.

Table.1 Interaction between mushroom fungi and C.gloeosporioides

\begin{tabular}{|c|c|}
\hline $\begin{array}{l}\text { Mushroom fungi with } \\
\text { C.gloeosporioides }\end{array}$ & Nature of interaction \\
\hline Ganoderma lucidum & Pathogen growth was retarded and pushed back. \\
\hline Auricularia polytricha & $\begin{array}{l}\text { Formation of light yellowish green pigment at the interaction } \\
\text { zone }\end{array}$ \\
\hline Lentinus edodes & $\begin{array}{l}\text { Clear zone of inhibition were formed ;both the mushroom and } \\
\text { pathogen did not grow each other }\end{array}$ \\
\hline Fomes spp & $\begin{array}{l}\text { Thick mat of hyphae were formed at zonal point and later } \\
\text { pathogen gets hyper parasitized by the mushroom fungi }\end{array}$ \\
\hline Volvariella volvacea & $\begin{array}{l}\text { The mushroom fungi hyperparasitised over the pathogen but no } \\
\text { inhibition zone }\end{array}$ \\
\hline Pycnoporus sanguineus & $\begin{array}{l}\text { No inhibition zone.A very thin zone were formed at contact } \\
\text { point }\end{array}$ \\
\hline Pleurotus florida & $\begin{array}{l}\text { No inhibition zone ;no hyperparasitization;both the mushroom } \\
\text { and the pathogen growth ceases at the point of interaction }\end{array}$ \\
\hline Schizophyllum commune & $\begin{array}{l}\text { Thick mat of mycelial hyphae were formed at the zonal point } \\
\text { and further growth of pathogen gets retarded }\end{array}$ \\
\hline Coprinus sinensis & No inhibition zone.Both fungi did not grow each other \\
\hline Calocybe indica & $\begin{array}{l}\text { Linear mycelial growth of the pathogen near the mushroom } \\
\text { fungi }\end{array}$ \\
\hline Tricholoma matsukae & Pathogen grow over the mushroom fungi \\
\hline
\end{tabular}


Table.2 Testing the efficacy of crude culture filtrate of G.lucidum and A.polytricha against C.gloeosporioides

\begin{tabular}{|c|c|c|c|c|}
\hline \multirow{2}{*}{$\begin{array}{l}\text { Days } \\
\text { interval }\end{array}$} & \multicolumn{2}{|c|}{ G.lucidum } & \multicolumn{2}{|c|}{ A.polytricha } \\
\hline & $\begin{array}{l}\text { Mean mycelial of the } \\
\text { pathogen Growth }\end{array}$ & $\begin{array}{l}\text { \% inhibition } \\
\text { over control }\end{array}$ & $\begin{array}{l}\text { Mean mycelial of the } \\
\text { pathogen Growth }\end{array}$ & $\begin{array}{c}\% \text { inhibition over } \\
\text { control }\end{array}$ \\
\hline $10^{\text {th }}$ day & $90.00^{b}(71.61)$ & 0.00 & $90.00^{c}(71.61)$ & 0.00 \\
\hline 15th day & $58.66^{\mathrm{a}}(49.96)$ & $34.88^{\mathrm{ab}}(36.18)$ & $52.33^{\mathrm{b}}(46.31)$ & $41.88^{b}(40.31)$ \\
\hline $20^{\text {th }}$ day & $57.33^{\mathrm{a}}(49.19)$ & $36.33^{\mathrm{a}}(37.05)$ & $47.60^{\mathrm{a}}(43.60)$ & $47.11^{\mathrm{a}}(43.32)$ \\
\hline $25^{\text {th }}$ day & $59.33^{\mathrm{a}}(50.35)$ & $34.11^{b}(35.71)$ & $51.33^{b}(4.74)$ & $43.00^{b}(40.95)$ \\
\hline Control & $90.00(71.61)$ & 00 & $90.00(71.61)$ & $0.00^{\mathrm{d}}$ \\
\hline SEd & 1.265 & - & 1.235 & - \\
\hline $\begin{array}{c}C D \\
(p=0.05)\end{array}$ & 2.854 & - & 2.787 & - \\
\hline
\end{tabular}

Values are the mean of three replications. Means followed by a common letter are not significantly different at 5\%level by DMRT. Values in parenthesis are arcsine transformed values.

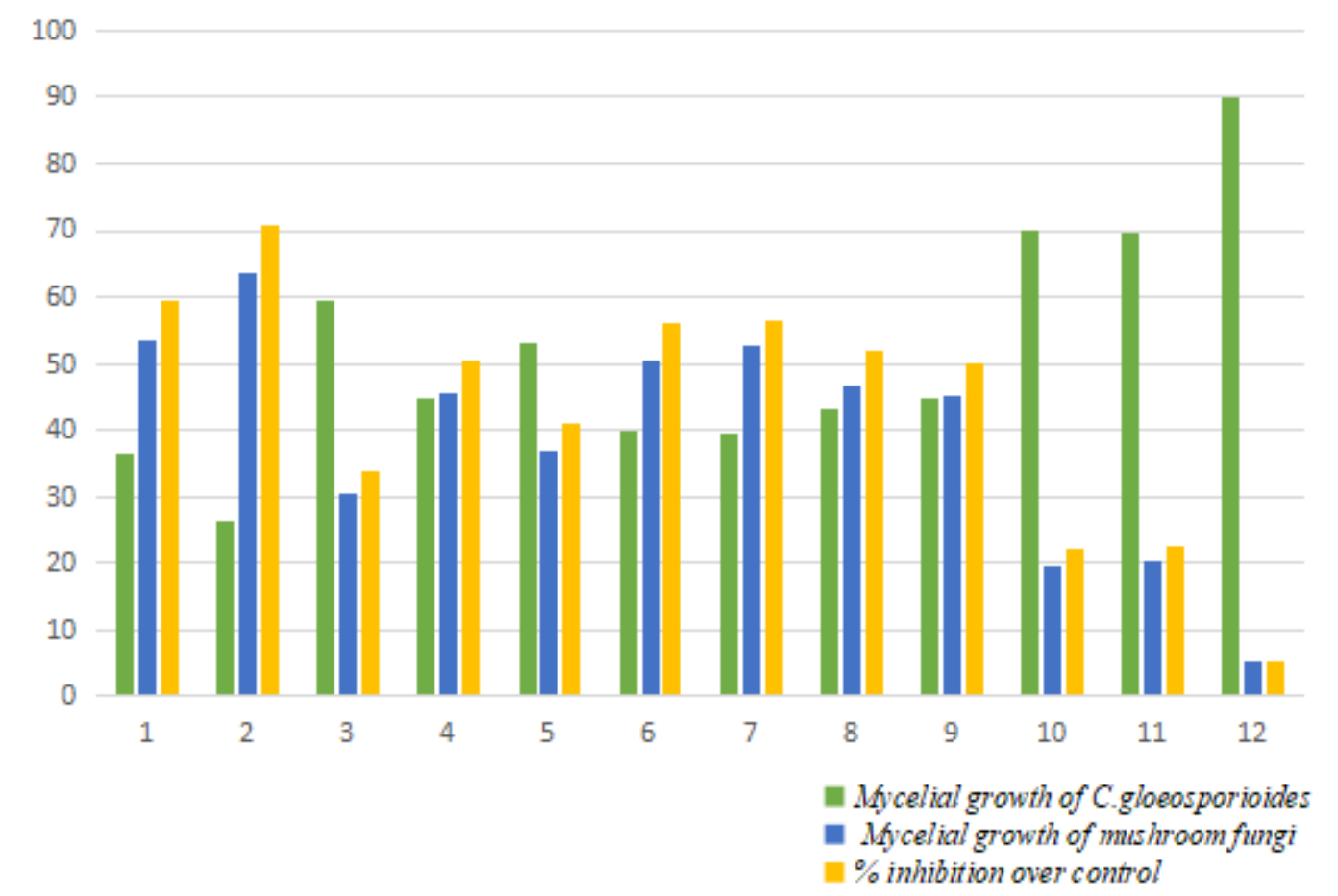

1. Ganoderma lucidum

2. Auricularia polytricha

3. Lentinus edodes

4. Fomes spp

5. Volvariella volvacea

6. Pycnoporus sanguineus

Fig.1 Screening the antagonisitic activity of mushroom fungi against $C$.gloeosporioides
7. Pleurotus florida

8. Schizophyllum commune

9. Coprinus sinensis

10. Calocybe indica

11. Tricholoma mastukae

12. Control

by dual culture assay 
Ganoderma lucidum

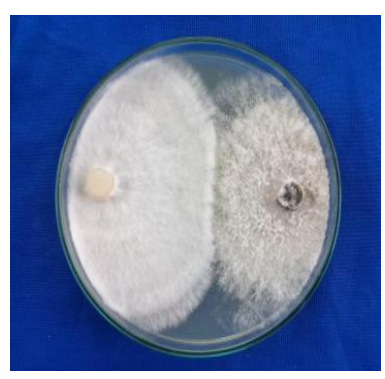

Fomes spp

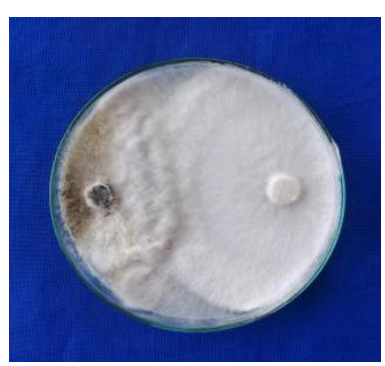

Pleurotus florida

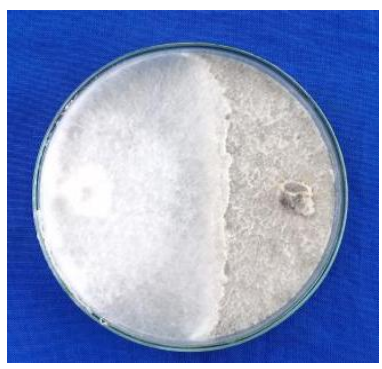

Calocybe indica

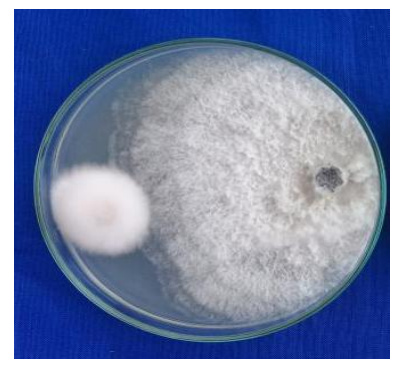

Auricularia polytricha

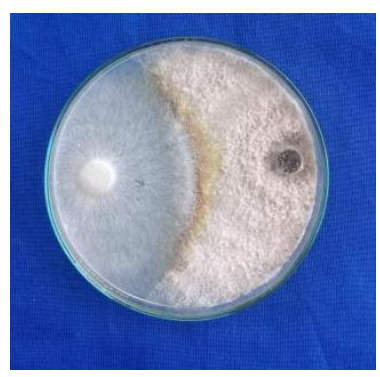

Volvariella volvacea

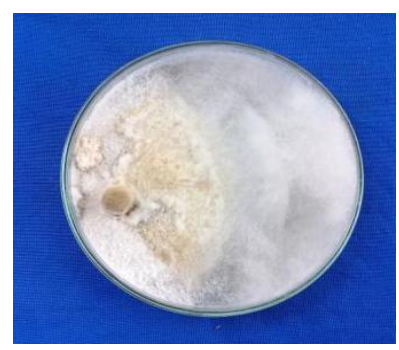

Schizophyllum commune

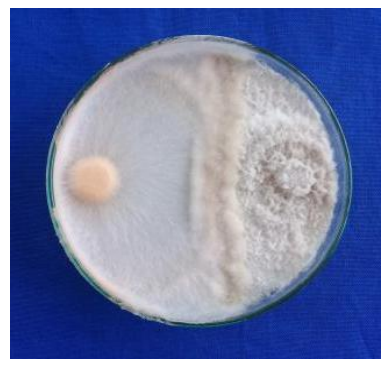

Tricholoma mastukae

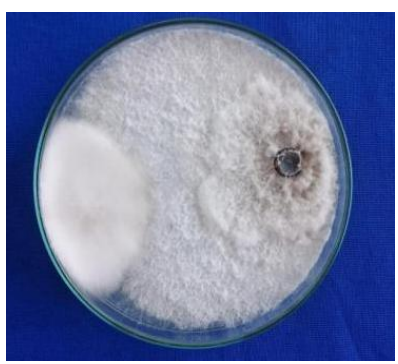

Lentinus edodes

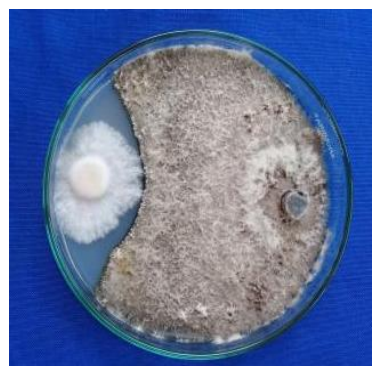

Pycnoporus sanguineus

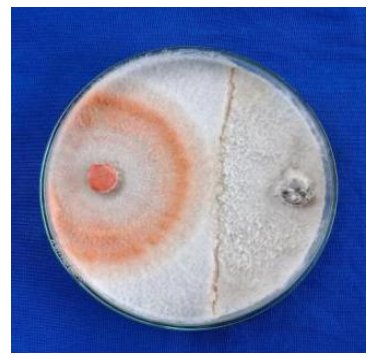

Coprinus sinensis

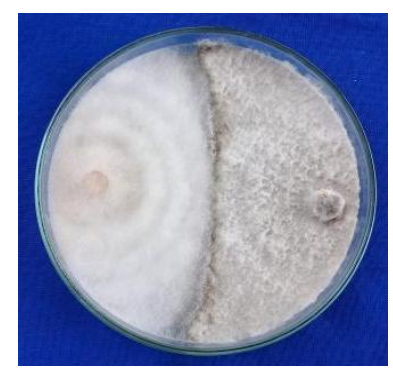

Control

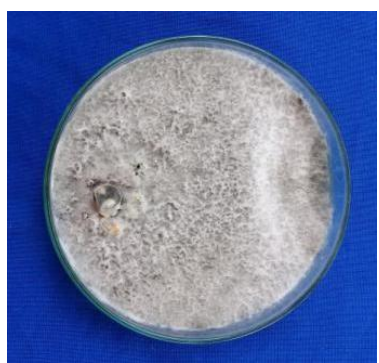

Plate.1 In vitro effect of antagonistic activity of mushroom fungi against Colletotrichum gloesporioides by dual culture 

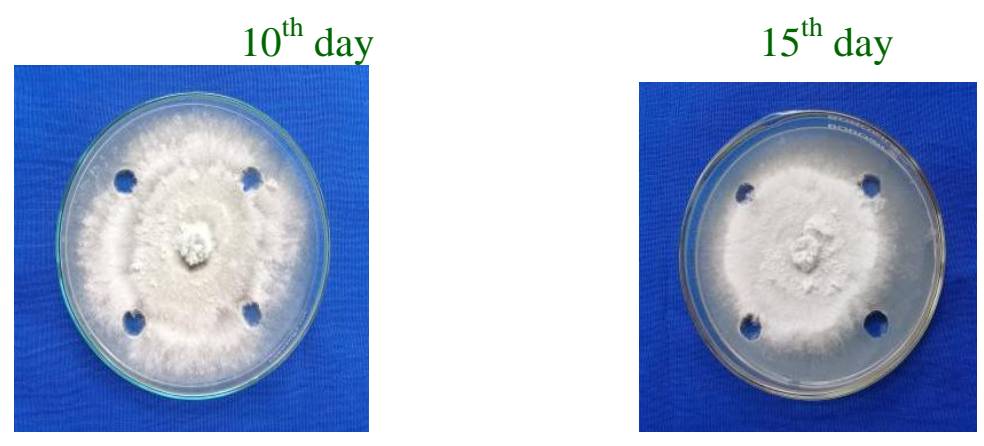

$20^{\text {th }}$ day
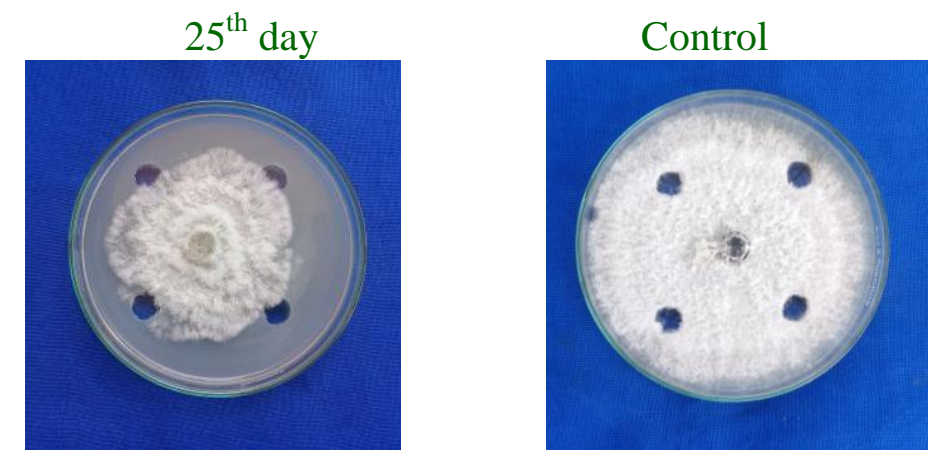

Plate.2a Antimicrobial activity crude culture filtrate of Ganoderma lucidum and against Colletotrichum gloeosporioides
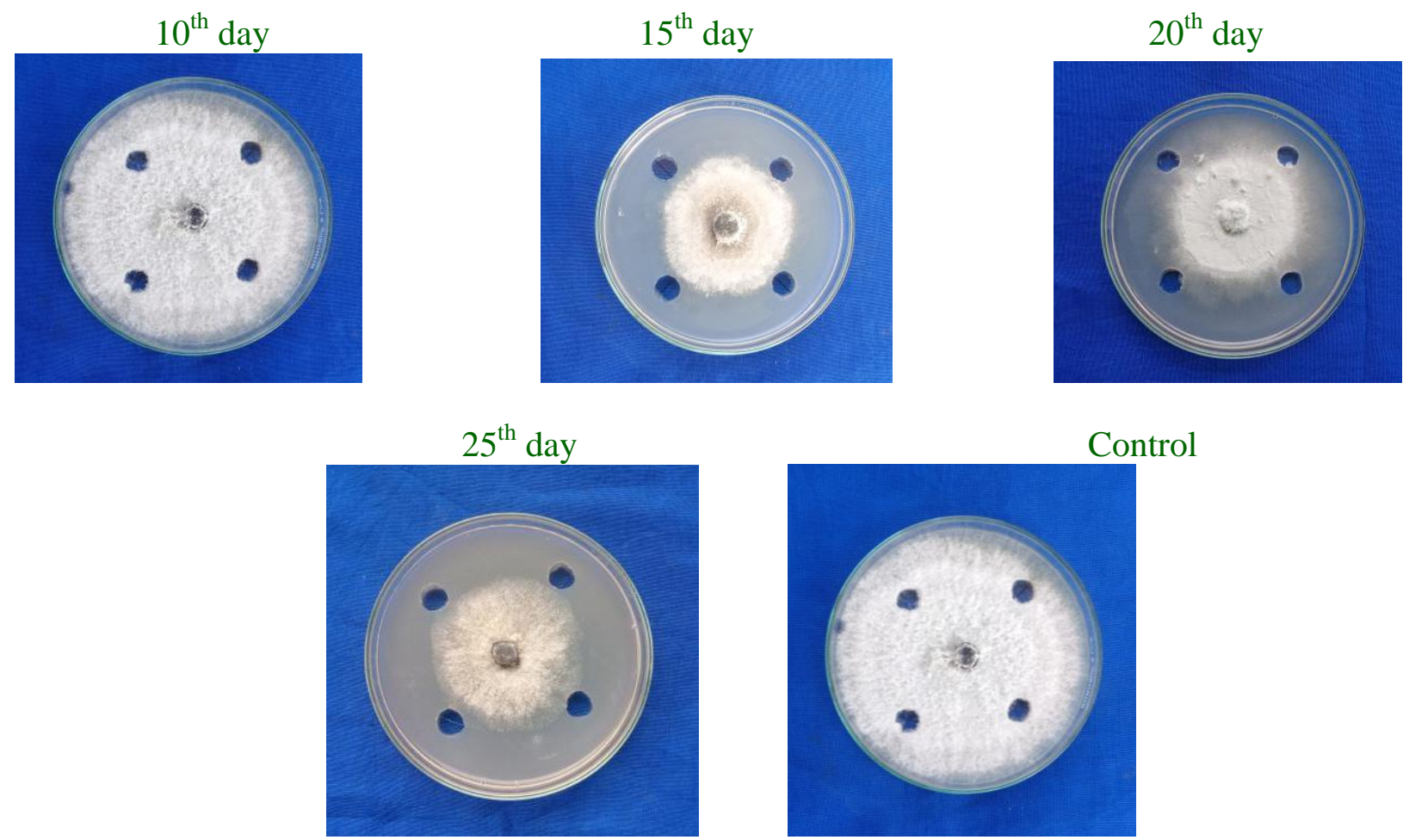

Plate.2b Antimicrobial activity crude culture filtrate of Auricularia polytricha against Colletotrichum gloeosporioides 
Testing the efficacy of crude culture filtrate from potential mushroom fungi Ganoderma lucidum and Auricularia polytricha against $C$.gloeosporioides

Based on the maximun inhibition per cent and interaction studies the culture filtrates of G.lucidum and A. polytricha collected at various periodical interval $10^{\text {th }}, 15^{\text {th }}, 20^{\text {th }}$ and $25^{\text {th }}$ days were tested to exploit the antimicrobial metabolites against C.gloeosporioides, Results indicated that the crude culture filtrate collected on $10^{\text {th }}$ day did not exhibit any antifungal effect against any the pathogen tested.The culture filtrate collected from $20^{\text {th }}$ day showed maximum mycelial inhibition of $36.33 \%$ and $47.11 \%$ of C.gloeosporioides with respect to G. lucidum and A. polytricha respectively (Table 2; Plate $2 \mathrm{a}$ and $\mathrm{b})$.

From the findings, it is concluded that antagonistic effect of mushroom fungi by dual culture assay may offer an indication for the presence of antimicrobial metabolites and such tests will be useful to screen large number of samples. In our study, the mushroom G. lucidum and A.polytricha secreted maximal production of antifungal metabolites on $20^{\text {th }}$ day and contributed for maximum inhibition of mycelial growth of C.gloeosporioides.

Globally research is focused on the development of newer fungicide through approaches to manage the plant diseases to mitigate the pesticide residues in food channel. This study further implies that the mushroom fungi screened against C.gloeosporioides possess antagonistic activity with various interactions such as formation of inhibition zone, thick mat of mycelium and hyper parasitic activity. Among them the need for identification of bio active compounds from the G. lucidum and A. polytricha is required for developing fungicide against broad spectrum activity. The study paves way and kindles interest for identification of the antimicrobial compound in A. polytricha and G. lucidum responsible for inhibition of pathogen growth.

\section{Acknowledgement}

The author thanks the University for providing facilities through the scheme UGCSAP DRS1 on Mushroom biotechnology to carry out the research work.

\section{References}

Akem, C.N., 2006. Mango anthracnose disease: Present status and future research priorities. Plant Pathol. J., 5: 266-273.

Arauz, L.F. 2000.Mango anthracnose: economic impact and current options for integrated management. Plant Disease, 84, p. 600-611

Badalyan, S. M., Gharibyan, N. G., Innocenti, G. 2014. Antifungal/Antagonistic Activity of Different Ganoderma Collections against Plant Pathogenic Fungi and Their Antagonists. 8th international conference on mushroom biology and mushroom, 4.

Badalyan, Susanna Michael, Gloria Innocenti, and Narine Grigory Garibyan. 2002. "Antagonistic activity of xylotrophic mushrooms against pathogenic fungi of cereals in dual culture." Phytopathologia Mediterranea 41 (3):220-225.

Chen, JT. and Huang, JW. 2010. Antimicrobial Activity of Edible Mushroom Culture Filtrates on Plant Pathogens Plant Pathology Bulletin 19: 261-270.

Chowdhury, M.N.A. and M.A. Rahim, 2009. Integrated crop management to control anthracnose (Colletotrichum gloeosporioides) of mango. J. Agric. 
Rural Dev., 1-2: 115-120.

Dennis, C and Webster, J. 1971. Antagonistic properties of species-groups of Trichoderma: II. Production of volatile antibiotics. Transactions of the British Mycological Society, 57(1), 41-IN44.

Hatvani, N. 2001. Antibacterial effect of the culture fluid of Lentinus edodes mycelium grown in submerged liquid culture. International Journal of Antimicrobial Agents, 17(1), 71-74.

Jeeva, S. and Krishnamoorhy, A.S. 2018.Antifungal potential of Mycomolecules of Coprinopsis cinerea (Schaeff) S.Gray s.lat against Fusarium spp, Madras Agric J., 105(1-3): 56-60.

Jha, S.N., Narsaiah, K., Sharma, A.D., Singh, M., Bansal, S., Kumar, R., 2010. Quality parameters of mango and potential of non-destructive techniques for their measurement-A review. Journal of Food Science and Technology 47, 1-14.

Lakshmi, B.K.M., P.N. Reddy and R.D. Prasad, 2011. Cross-infection potential of Colletotrichum gloeosporioides penz. Isolates causing anthracnose in subtropical fruit crops. Trop. Agric. Res., 22: 183-193

Lindequist, U., Niedermeyer, T. H., and Julich, W.D. $2005 . \quad$ The pharmacological potential of mushrooms. Evidence Based Complementary and Alternative
Medicine, 2(3), 285-299.

Poucheret, P.; Fons, F.; Rapior, S. Biological and pharmacological activity of higher 477 fungi: 20-Year retrospective analysis. Mycologie, 2006, 27, 311-333.

Priya, K., G. Thiribhuvanamala, A. Kamalakannan and Krishnamoorthy, A.S. 2019. Antimicrobial Activity of Biomolecules from Mushroom Fungi against Colletotrichum capsici (Syd.) Butler and Bisby, the Fruit Rot Pathogen of Chilli. Int.J.Curr.Microbiol.App.Sci. $\quad$ 8(06): 1172-1186.

Quang, D.N., Hashimoto, T., Asakawa, Y. 2006: Inedible mushrooms: A good source of biologically active substances. Chem. Record. 6: 79-99.

Shad, M.A., Ansari, T.M., Pervez, H., Rubab, M. and Mahmood, T. 2002. Department of Chemistry, Bahauddin Zakariya University, Multan-60800, Pakistan mango research station, Shujabad, Punjab, Pakistan. Online J. Biol. Sci., 2: 694-696.

Stokes, EJ, and GL Ridgway. 1980. "Antibacterial drugs." Clinical bacteriology: 200-254.

Vincent, JM. 1947. Distortion of fungal hyphae in the presence of certain inhibitors. Nature 159:850-850.

Wasser, SP. 2002. Review of Medicinal Mushrooms Advances: Good news from old Allies. Herbal Gram 56: 28-33.

\section{How to cite this article:}

Gayathri. M., G. Thiribhuvanamala and A. S. Krishnamoorthy. 2020. Harnessing the Antimicrobial Prospects of Mushroom and Fungi against Colletotrichum gloeosporioides Penz. Causing Post-Harvest Anthracnose Disease of Mango. Int.J.Curr.Microbiol.App.Sci. 9(07): 281-289. doi: https://doi.org/10.20546/ijcmas.2020.907.030 